\title{
ON THE MUTABILITY OF CHRIST
}

\author{
Axel Arturo Barceló Aspeitia \\ https:/ / orcid.org/0000-0002-0693-5910 \\ UNAM - Instituto de Investigaciones Filosóficas \\ Coyoacán, Ciudad de México \\ Mexico \\ abarcelo@filosoficas.unam.mx
}

\section{Article info \\ CDD: 165 \\ Keywords \\ Mutability \\ Christology \\ Pluralism \\ Change \\ Properties}

Received: 11.06.2021; Revised: 26.10.2021; Accepted: 28.10.2021

https://doi.org/10.1590/0100-6045.2021.V44N4.AB

\begin{abstract}
I argue that an ontological pluralist strategy that relies on category-relative properties is immune to all the particular criticisms Beall wields in his book against other strategies for recovering the consistency of the immutability of the incarnated god.
\end{abstract}

In The Contradictory Christ, Jc Beall (2021) advances a contradictory christian theology, i.e., he advocates for a glut-theoretic solution to "the so-called fundamental problem of christology... namely, the apparent contradiction of Christ's being fully human and fully divine" (Beall 2021: xvii). For Beall, Christ is a contradictory being, i.e., a being of whom some claims are both true and false. In particular, he is both (absolutely, fully, to the same degree and in the same sense) mutable and immutable. 
Besides defending this view, Beall also reviews competing solutions which he ultimately finds lacking, in comparison to his own. His case against them is constituted by two independent strategies. The first one is a general argument from simplicity, which he reiterates throughout the book. According to it, the contradictory solution is just simpler, and hence, all other, more complicated proposals, are unmotivated. This argument is specially yielded against pluralist accounts that try to recover the consistency of Christ by introducing metaphysical or semantic distinctions. For example, regarding proposals that appeal to innovative metaphysical distinctions, he writes:

There's nothing whatsoever wrong with finding the true metaphysics; that project should continue - just as the project of finding the true physics, true biology, and so on should continue. But to stake the truth of Christ on such projects, at least when the 'problem' has a ready and simple solution, appears to stake too much. Again, were there some very good reason to reject the simpler contradictory solution, there'd thereby be increased motivation for the compositional accounts. (Beall 2021: 128)

And regarding pluralist strategies that postulate semantic distinctions, he also retorts that they also must be seen as "a last resort, an option taken only when there are no other viable candidates for the truth." (Beall 2021: 134)

Besides this general strategy, Beall also presents more specific arguments against particular strategies for recovering the consistency of Christ, and even though the first argument is probably deeper and more interesting from a philosophical point of view - after all, it has to do with deep questions about how to determine who has the burden of proof, what 
is the true cost of a contradictory Christ, etc. - in this brief commentary I will focus on one of the later ones. In particular, I will argue that a reduplicative strategy that relies on keeping the divine and human ontologies separated is immune to the particular criticisms Beall wields against consistency preserving strategies, and thus one that we ought to take more seriously.

In the following, I will suscribe to Beall's characterization of reduplicative strategies - what he also calls qua-strategies as those according to which the apparent contradiction between the claims (1) and (2), hides an equivocation in either the subject term "Christ", the sentence's copula, or the predicate "mutable". To distinguish between these three variations of the qua- strategy, I will also follow Beall in calling them QUA1, QUA2 and QUA3 respectively.

1. Christ is immutable.

2. Christ is mutable.

So, for example, a QUA1 strategy would claim that (1) and (2) are equivocal and that what the christian dogma states about the mutability of Christ is better represented by (3) and (4) (Beall 2021: 41):

3. Christ-qua-divine is immutable.

4. Christ-qua-human is mutable.

According to Beall, the main problem with reduplicative strategies is that they fail to solve the problem at hand and instead change the subject. For example, when trying to recover consistency by arguing that Christ-qua-divine is immutable, while Christ-qua-human is not...

...one wonders why we're now talking about these other two subjects - namely, Christ-qua- 
divine and Christ-qua-human - when our principal focus was supposed to be Christ. One wonders why we're now multiplying subjects beyond Christ himself. (Beall 2021: 123)

However, one might well think that accusing a reduplicative strategy of changing the subject is question begging in so far as a central claim of this sort of proposals is precisely that there is something deficient, something ambiguous, in the original question that needs to be resolved before we can properly answer it. In other words, what reduplicative strategies are proposing is precisely to change the subject. In this case, the proposal is precisely that we must not ask whether or not Christ is immutable or not, but instead whether Christ-qua-human and Christ-qua-divine are. In a similar fashion, Beall's claim here is not simply that his strategy is more ontologically parsimonious because it does not multiply entities by introducing two new entities where there seemed to be just one. That, again, would be question begging against reduplicative strategies, since the very point of strategies of this sort is precisely to introduce new ontological distinctions, with all their due ontological costs. Beall himself recognizes this, as can be read in the first passage quoted at the top of this commentary. Instead, his point is both deeper and more subtle. His point here is that the metaphysical distinction this strategy introduces is radically inconsistent with counciliary orthodoxy. In other words, it is not so much that the claim that, at a metaphysically more fundamental level, there are two Christs, and not one, is ontologically un parsimonious, but that it is heretical. Christ is one as much as he is divine and as much as he is human.

I find this criticism fair enough regarding the first quastrategy, but it is not obvious that it applies to other quastrategies, specially to what he calls QUA 3 strategies. In reduplicative strategies of this sort, the qua-device applies to 
predicates, so that consistency is preserved because of the lack of contradiction between (5) and (6):

5. Christ is immutable-qua-divine.

6. Christ is mutable-qua-human.

Beall claims that he focuses on QUA 1 arguments because his arguments against them apply mutatis-mutandi to the other versions. But, as I will argue, this is not so. For starters, notice that if we tried to paraphrase the above charge of change of topic from subjects to predicates, we would have to say something like...

...one wonders why we're now talking about these other two properties - namely, immutable-qua-divine and mutable-qua-human when our principal focus was supposed to be immutability. One wonders why we're now multiplying properties beyond immutability himself.

However, the resulting rhetorical question loses a lot of its bite. This is because, unlike QUA 1, QUA 3 does not shift "the principal subject matter of christology away from Christ." (Beall 2021: 123) Beall is right that:

...an account that shifts the principal focus away from Christ - as the principal property bearer of all given divine and all given human properties - is prima facie worse (because prima facie off-topic) than an account that keeps Christ as the fundamental bearer of the given properties. (Beall 2021: 125, n.5) 
But QUA 3 keeps Christ in focus as the principal property bearer of all of his divine and human properties. It does not change the subject, as QUA 1 strategies do, because the subject matter of Christology is Christ, not change or mutability. The theoretical cost of postulating a distinction in Christ's nature is not comparable with the cost of introducing a distinction in the property of mutability. Yes, just as in QUA 1 strategies, a new ontological distinction is introduced, i.e., where we thought there was only one property - mutabilitythere are actually two - mutability-qua-human and mutability-qua-divine. By distinguishing between these two properties, QUA 3 weakens the entailments of the predicate "mutable" and thus qualifies as a sort of downstream strategy in Beall's terminology. As such, it involves "structural" changes in the systematic framework" (Beall 2021: 135) and accordingly, Beall could well argue that a proposal like his, that leaves "the meanings of core christological predicates (e.g., "divine", "immutable", etc.) in place, is a prima facie better [option] than to muck with said predicates." (Ibidem) Alas, this just takes us back to the first, controversial general argument that Beall's contradictory Christology is just simpler, and thus tells us nothing specific about this QUA 3 proposal.

There is indeed a multiplication of properties, but this should not directly count against this qua- strategy, as has been established above. This is just part of the project of finding the true metaphysics. However, this does not mean that we should just accept any ontological distinction that is postulated. There is ample room for ontological criticism. For starters, there is something deeply unsatisfying in trying to avoid a contradiction by introducing a distinction ad-hoc. Whoever wants to propose a reduplicative strategy like this ought to show that the distinction they introduce is not gratuitous. This can be achieved by showing that the distinction captures a genuine difference in the phenomenon. This means that the distinction should make sense and play some 
theoretical role outside the context of the contradiction it is introduced to dissolve. As I hope to show now, unlike the QUA 1 strategy, this is something that can be shown about the distinction introduced by the QUA 3 strategy, in so far as it is grounded on distinctions regarding properties that are independently motivated. Thus, I conclude, this QUA 3 strategy is still worth considering as a strong an alternative as Beall's glut-theoretic solution.

Christ went from being born, to being baptized, then crucified, and finally resurrected. To show how this is consistent with Christ being immutable-qua-divine we need to give a metaphysical account of what the qua- device does in general, and how it applies to the "mutable" predicate in particular. Our metaphysical toolbox is furnished with many possible solutions, and in this commentary I will focus on a very simple and straightforward one. The first step is to sort predicates by their domain of application (for a more formal development of these ideas, see Freund 2018). As is widely accepted, but not completely uncontroversial, there are individuals that belong to more than one different ontological category. A well known couple of examples are the sculpture that is also a lump of clay or the kitten which is also a cat (Grandy and Freund 2021). Just like them, Christ also belongs to two different ontological categories as he is both divine and human. A well known puzzle about objects of this sort is that they seem to either violate Leibniz law of indiscernibility of identicals or the Aristotelean law of noncontradiction. For example, while a sculpture may be rare or fragile, the lump of clay seems to be none of these things. Thus, it would seem that this clay sculpture is both rare and not rare, fragile and not fragile, etc. (Wasserman 2018) A way out of this contradiction is to argue that predicates like "rare", "fragile", etc. are sorted in such a way that entities that belong to one category can have a property qua-onecategory but not the corresponding homophonic property 
qua-another. Thus, the same single object can both be rarequa-sculpture but not rare-qua-lump-of-clay without falling into contradiction or violating Leibniz's law (since being rare-qua-sculpture and not rare-qua-lump-of-clay are two genuinely different properties). ${ }^{1}$ The same thing happens with Christ, who is both mutable-qua-human and immutable-qua-divine, as we will see next.

Now, the next step is to sort God's properties in those he has or can have because he is human - let's call them his human properties - and those he has or can have because he is god - let's call them his divine properties. With this distinctions in place, we can now distinguish between God's property of being mutable-qua-human, which would just mean being able to change from having a human property to not having it or vice versa, and the property of being mutable-qua-god which would involve the capacity of acquiring or losing divine properties. Presumably "being born" expresses a human property, not a divine property. Accordingly, this is one of the properties Christ can lose because he is mutable-qua-human. Among the things the council says of Christ, divine properties would be: being the only-begotten Son of God, being the true God, being consubstantial with the Father and being creator of all things (that are created). These properties Christ did not acquire nor lose before, during or after his human life (Pawl 2018). This is what makes Christ immutable-qua-divine.

\footnotetext{
1. For objects or properties that belong to a single ontological category, there is no need to make the "qua-"clause explicit,: the property expressed by the predicted " divisible by six", for example, cannot be but the property of being divisible-by-six-qua-integer. Other predicates, like " fragile" and, as we will see, "mutable", however, can be ambiguous and thus fort them it is helpful to some times make the "qua-" clause explicit.
}

Manuscrito - Rev. Int. Fil. Campinas, v. 44, n. 4, pp. 363-373, Oct.-Dec. 2021. 
Now, there is nothing contradictory in the fact that God is mutable-qua-human, because he acquired and lost many of his human properties during his life, but immutable-quadivine because he cannot change any of his divine properties. Thus, the claim that Christ is immutable-qua-divine "capture[s] the full intent the councils had when asserting that Christ was immutable" (Pawl 2018: 921) and, in the inverse direction, the notion that Christ was mutable-qua-human helps account for Christ going from being born, to being baptized, then crucified, and finally resurrected.

We do not say that his flesh was turned into the nature of the godhead or that the unspeakable Word of God was changed into the nature of the flesh. For he (the Word) is unalterable and absolutely unchangeable and remains always the same as the scriptures say. For although visible as a child and in swaddling cloths, even while he was in the bosom of the virgin that bore him, as God he filled the whole of creation and was fellow ruler with him who begot him. (Tanner 1990: 51)

Consequentially, saying that Christ is immutable-qua-divine is neither to say that he is divine and immutable, nor to say that Christ is immutable because he exemplifies the divine nature, both of which would be assailable by Beall's arguments in (2021). The point is that there is no such property as mutability. There is a "mutability" predicate, but it is ambiguous. The property it expresses is constrained by the sort of entity it is applied to. Thus, it can be used to express different properties, like "mutable-qua-human" or "mutablequa-divine" in different contexts. Usually, this does not generate any confusion, because most entities belong to a single category, but Christ is not like most entities and thus here we 
need to appeal to something like a qua- mechanism to avoid equivocation and the appearance of contradiction.

In this way, the QUA 3 strategy can provide a consistency preserving solution to the fundamental problem of christology, because it is consistent both with the content of counciliary texts and with what we know about the ontology of properties and change. Moreover, QUA 3 satisfies the further requirement that "Christ is the bearer of all such properties (viz., all those properties entailed by either divinity or humanity) - the primary, fundamental bearer of all such properties." (Beall 2021: 126) Thus, it does not depart from what Beall himself calls "the simple and core picture." (Ibidem) It is Christ, fully and primarily, the bearer of al these properties. It is not that there is some human part that was incarnated, but Christ himself and in full who was incarnated. ${ }^{2}$ It is also different from a relative identity strategy a la van Inwagen, since it does not postulate two 'consistentizing subjects': one exemplifying the divine properties of Christ, another exemplifying the human properties of Christ. In consequence, it is immune to Beall's criticism against QUA-1 strategies.

This means that, within the framework of Beall's "The Contradictory Christ", QUA 3 remains a strong contender among consistency restoring proposals, one that is worth considering as a plausible solution to the fundamental problem of Christology in so far as it is immune to the shortcomings Beall finds in other specific consistency preserving proposals. For sure, this does not mean that the proposal is not immune to other sorts of criticisms, or that no criticisms that have been brought up against other reduplicative strategies would apply to this one as well, but to address them would

\footnotetext{
2. Thus QUA-3 is not what Beall calls a compositional account either.
} 
escape the province of this book symposium and I must leave them for consideration on another occasion.

\section{References}

Beall, J.C. (2021) The Contradictory Christ, Oxford University Press.

Freund, M.A. (2018) "Predication and sortal concepts". Synthese: 1-22. https://doi.org/10.1007/s11229-01802030-7.

Grandy, R.E. \& Freund, M.A. (2021) "Sortals", The Stanford Encyclopedia of Philosophy (Summer 2021 Edition), Edward N. Zalta (ed.) URL $=<$ https://plato.stanford.edu/archives/sum2021/entries/sortals/>.

Pawl, T. (2018) Conciliar Christology and the Consistency of Divine Immutability with a Mutable, Incarnate God. Nova et Vetera, English Edition, 16(3): 913-937.

Tanner N. (1990) Decrees of the Ecumenical Councils, Georgetown University Press.

Wasserman, R. (2018) "Material Constitution", The Stanford Encyclopedia of Philosophy (Fall 2018 Edition), Edward N. Zalta (ed.), URL = <https://plato.stanford.edu/archives/fall2018/entries/material-constitution $/>$.

$(c)$ BY 